\title{
Public Participation: KL Draft City Plan 2020
}

\author{
Jamalunlaili Abdullaha, Che Bon Ahmad a, \\ Sri Rahayu Mohd Sa'ad a, Shariman Abdul Wahab b \\ a Faculty of Architecture, Planning and Surveying, \\ Universiti Teknologi MARA, 40450 Shah Alam, Selangor, Malaysia \\ b Master Plan Department, Kuala Lumpur City Hall, Malaysia \\ jamal858@salam.uitm.edu.my; bota65@yahoo.com
}

\begin{abstract}
Local Plan of every city in the world reflects its policies and public needs. Hence, it is vital to decide the suitable process representing the public voice. This paper analyses the process of public participation during the preparation of the Kuala Lumpur City Plan (KLCP). Its objective is to determine the levels of awareness and activism, and the planning issues, objectives, and comments that concern the public most. The outcome is expected to shed more insights into the process of public participation in planning in Malaysia concerning the urban development of the Malaysian capital.
\end{abstract}

Keywords: Keywords: Public participation; Kuala Lumpur Draft City Plan 20; participatory planning; Kuala Lumpur

eISSN: 2398-4295 @ 2016. The Authors. Published for AMER ABRA by e-International Publishing House, Ltd., UK.. This is an open access article under the CC BY-NC-ND license (http://creativecommons.org/licenses/by-ncnd/4.0/). Peer-review under responsibility of AMER (Association of Malaysian Environment-Behaviour Researchers), ABRA (Association of Behavioural Researchers on Asians) and cE-Bs (Centre for EnvironmentBehaviour Studies), Faculty of Architecture, Planning \& Surveying, Universiti Teknologi MARA, Malaysia.

https://doi.org/10.21834/ajbes.v1i3.35 


\subsection{Introduction}

In Malaysia, public participation is enshrined in its urban planning system. It is provided for under the Town and Country Planning Act of 1976 (Act 172). In it, the documents and plans prepared must be displayed to the public for them to make comments and objections. The comments and objections cover the National Physical Plan (NPP) at the national level, the State Structure Plan at the state level and the local plans at the district level. It is at the lowest level, i.e. the local plan level that public participation seems to be the most intensive, since it covers an individual lot of land of the public. Since the use and intensity of use are prescribed at the local plan level, as opposed to the national and state level which are more policy oriented in nature.

\subsection{Literature Review}

The human factors which come from public participation in an urban environment are very sensitive to the conditions of the physical environment. These factors determine the effective and harmonious community in an urban physical environment (Abdul Karim \& Abdul Rashid, 2010). Various public participation techniques are applied intensively throughout the planning process for examples, "Amphawa Model" - community conservation and regeneration model, is developed to help direct all strategies and policies. Thus, a partnership between the planner, the local community, and all related agencies must be established (Peerapun, 2011). It is suffices to say that efficient public participation can help decision makers and planners to achieve better planning alternatives (Wanarat \& Nuanwan, 2013).

\subsection{Purpose of study and study area}

This paper analyzes the public views and consent which will be translated into the local plan. The Kuala Lumpur City Plan (Local Plan) which was adopted by the Kuala Lumpur City Hall in 2010 was a detailed land use plan for Kuala Lumpur until 2020. It translated the Structure Plan policies into an individual lot land use development plan. The process of preparing the City Plan underwent a significant public participation process especially in the Focus Group Discussion during the preparation stage and the Public Objection stage after the unveiling of the Draft City Plan. During the latter stage over 6000 comments and objections were received from the public. This paper analyzes the process of public participation during the preparation of the local plan. Its main objective is to determine the levels of awareness and activism of the Kuala Lumpur residents in relation to land use plans and policies proposed by the Kuala Lumpur City Hall. It covers both stages mentioned above, but the focus would be more on participation during the public objection stage since it was during this stage where the participations of the residents were perhaps more pronounced and engaging. Kuala Lumpur Draft City Plan 
After a few years of preparation by a team of local consultants, the Kuala Lumpur Draft City Plan 2020 was submitted to the Kuala Lumpur City Hall. This local plan is part of the development plans provided in Part III of Act 267, Federal Territories (Planning) 1982. While the Kuala Lumpur Structure Plan, which was gazetted in 2004 spelled out policies and development strategies of Kuala Lumpur until the year 2020, the local Plan (Draft City Plan) translates them into detailed development plans. It covers the period until the year 2020 as well. The draft local plan consists of a written statement which states in detail proposals for development and use of land for improvement of the environment from a physical perspective and to improve transportation (Federal Territory Planning Act, 1984).

There were four volumes of the KLDCP, which contain land use maps supported by written statements. They covered every lot within the Federal Territory of Kuala Lumpur. However, only three volumes were made available for public inspections. Publicity about the plan was made through notices and mass media. During the inspection period, the public and government departments were invited and encouraged to participate through the Public Opinion Hearing. Respondents were required to submit comments, opinions and objections using a Public Opinion form which can be submitted manually or electronically. This is the start of the public hearing process of the Kuala Lumpur Draft City Plan.

During the preparation of the plan before it was submitted for inspection, public participation was already included in the process. This is done through a survey of the people and land, interviews with stakeholders and focus group discussions. Perhaps it was during the focus group discussion sessions where the public was able to state their problems and aspirations of the plan while it is being prepared. Planning consultants and City Hall planning officers would listen and note opinions and suggestions forwarded by people selected to be in the focus group discussions who tend to be community and business leaders. These suggestions, in addition to other primary and secondary data collected and analyzed by the consultants, formed the basis of the development of the plans. However, this paper does not go into public participation during the preparation of the Draft City Plan; rather it focuses on public participation in the inspection period and public hearing conducted in response to the completed and displayed local plan. Perhaps, this presents a more accurate assessment of public participation since during this stage, the publicity for public responses are more widespread, and the opportunities are given to everybody unlike during the focus group discussion when invitations tend to send to selected few.

\subsection{Methodology}

The flowchart below shows the complete process of preparing the KLCP. Eventually, this paper focuses on the public objection or opinions process after the draft plan was unveiled to the public. The study uses a qualitative approach. The analyses would determine individuals and groups involved as well as the planning issues that concern them most. The 
analysis tends to be descriptive in nature relying on documents in Kuala Lumpur City Hall related to public participation and objections and comments to the plan. It is also based on the experiences of the main author as one of 18 committee members appointed by the Mayor of Kuala Lumpur to listen and make recommendations for objections and comments of the public. It groups the respondents and issues they represent into several possible themes such as economic, environmental or social.

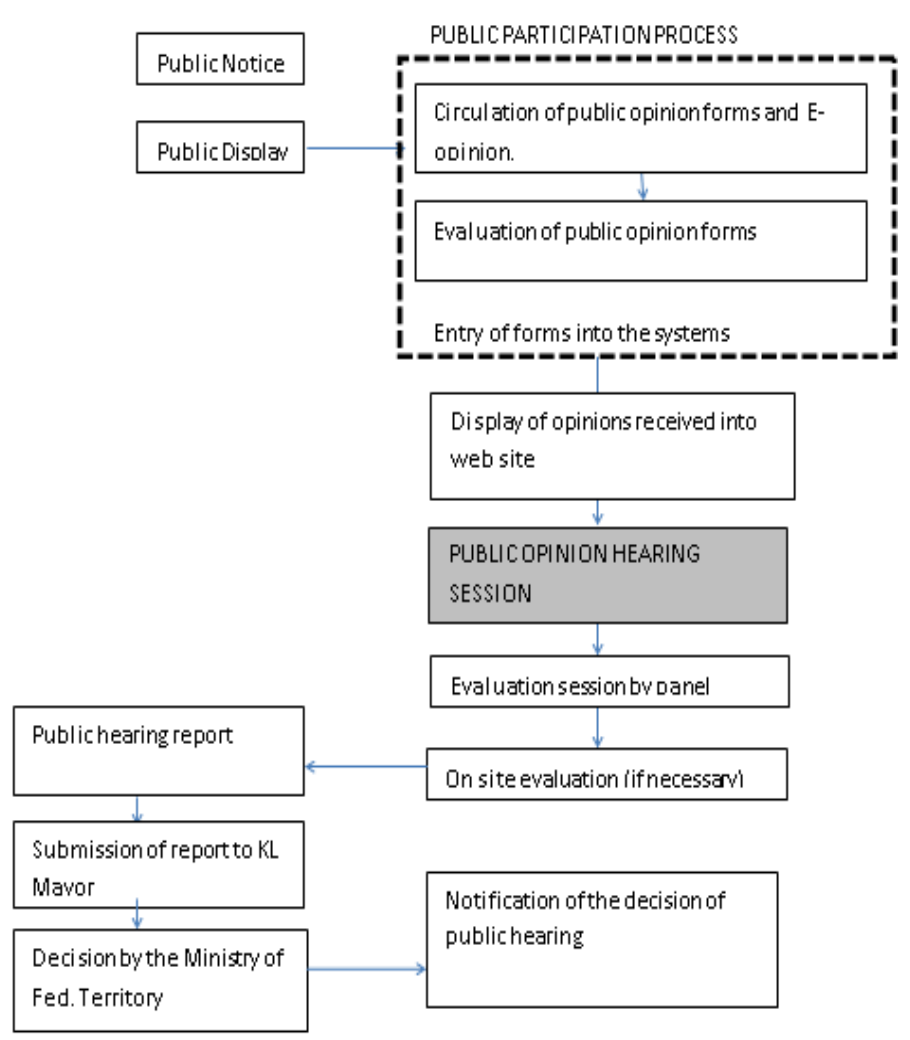

Figure 1: Flowchart of public participation hearing process (Source: Draft Kuala Lumpur 2020, DBKL, 2009)

\subsection{Public participation in the draft city plan}

Exhibitions of the Kuala Lumpur Draft City Plan 2020 started officially after the plan was launched by the Federal Territory Minister in May 2008. The exhibition of the plans was conducted in two methods: permanent (static) exhibition at the Kuala Lumpur City Hall and temporary (movable) exhibitions in major shopping malls, community halls and public 
transport terminals. Its purpose were to inform the public about the local plan, its contents which covers development proposals and proposed use of land, and to provide opportunities for the public to air their views and objections during the public hearing session. It ultimate goal is to produce a land use development plan which is fair and equitable that considers the interests of the people.

Under the government gazette, the plan was exhibited for the public inspection for a period of one and a half month, from May 15th until June 30th 2008. However, due to the public request, the mayor extended the period for people to submit views and objections until August 30th 2008. It shows that the Kuala Lumpur City Hall was sincere in encouraging the people to participate and provide comments towards the plan.

\subsection{Official comments and objections from the public}

At the end of the three and a half month period allocated to the public a total of 5,052 representations (individuals and groups) were received from the public. This figure is a very significant increase compared to other local cities and towns local plans which drew at most only a few hundred responses. Although the figure represents only about 0.28 percent of Kuala Lumpur population the actually number of the people involved were actually much higher since a group representation is counted as one although they are signed by many individuals. A petition by one of the groups was signed by more than 7,000 people.

Of these representations to Kuala Lumpur City Hall, 93.4 percent were submitted manually while 6.6 percent were submitted on-line. 77.3 percent of representations were individuals while 22.7 percent were groups which show perhaps the independence of petitioners. Surprisingly, 3411 representations ( 67.5 percent) wanted to attend the public hearing session where they can present verbally their comments, suggestions and objections to the local plan. This is perhaps an indication of the seriousness of the public to be heard since they would make an effort to present their cases in front of the public hearing committee. Those who decline to attend the public hearing session would have they comment and objections considered by the panel without their presence. (KL City Hall, 2010)

Since each representation can submit more than one comment or objection in the form, some decided to include a few issues and objectives. Thus, there were 62,224 opinions, comments and objections that have to be heard by the public hearing committee.

\subsection{Public hearing process}

In order to decide on the 62.224 opinions officially submitted to the Kuala Lumpur City Hall, the Mayor of Kuala Lumpur appointed a Public Opinion Hearing Committee composed of 19 individuals representing local universities, retired City Hall officers and representatives of non-governmental and professional bodies. This is provided under the Federal Territory Planning Act (Act 267). The committee was tasked with reading the opinions/objections submitted, listening to the oral presentations of representatives and to come up with the decisions to be forwarded to the Mayor for his final decision. 
The Public Opinion Hearing Committee was formed into different panels which met in 138 sessions from September 4th 2008 until May 28th 2009, a period of 9 months. In addition, five local investigations were carried out whereby the panel members visited the areas and met the residents for cases where closer inspection and understanding of the issues were necessary. For other cases, the panel relied on technical assistance and information from City Hall planners. All 66,224 opinions were considered during this session and all who requested to be heard personally were invited to present their opinions and objections before the panel.

\subsection{Results and Discussions}

All 62,224 opinions were grouped under 19 subject areas. Of these, the five subject areas that had the most opinions were transportation and transit planning zone, plan implementation and city management, zoning and land use, environmental protection and open spaces. The least number of opinions were those related to Vision of Kuala Lumpur, height restrictions and view corridor and urban redevelopments. This list of priority reflects issues that are often highlighted by the mass media as planning issues that are close to the hearts of the city residents.

Table 1: Summary of public hearing comments

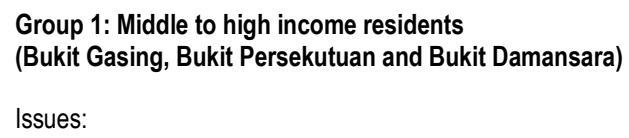

Zone \& land use

Residential land use

Control population density

Environmental protection

Protection of green areas and green lung

Open space

More public park and recreational ground

Group 2: Traditional Villagers

(Kampung Selayang Lama, Kampung Chubadak, Kampung Padang Balang

Sentul, Kampung Malaysia Tambahan dan Kampung Baharu) 
Issues:

$\begin{array}{ll}\begin{array}{l}\text { Transportation \& transit planning } \\ \text { zone }\end{array} & \begin{array}{l}\text { LRT line, transit, station. } \\ \text { Tunnel way } \\ \text { New and improved road system }\end{array} \\ \begin{array}{l}\text { Plan implementation \& city } \\ \text { management }\end{array} & \text { None } \\ \text { Zone \& land use } & \begin{array}{l}\text { Intensity \& density of residential area } \\ \text { City \& central development } \\ \text { Development continuation } \\ \text { Land status, ownership and reparation } \\ \text { Community centre }\end{array} \\ & \begin{array}{l}\text { Come } \\ \text { Environmental protection }\end{array} \\ \text { Open space } & \text { None }\end{array}$

\section{Group 3: Professional bodies (PAM)}

Issues:

$\begin{array}{ll}\begin{array}{l}\text { Transportation \& transit planning } \\ \text { zone }\end{array} & \text { Improvement of transportation systems } \\ \begin{array}{l}\text { Plan implementation \& city } \\ \text { management }\end{array} & \begin{array}{l}\text { Discrepancies and rigidity of development } \\ \text { plan }\end{array} \\ \text { Zne \& land use } & \text { Unbalance density/plot ratio } \\ \text { Environmental protection } & \text { River revitalization } \\ \text { Open space } & \text { More green space and public pedestrian }\end{array}$

\section{Group 4: NGOs}

Issues:

Transportation \& transit planning zone

Plan implementation \& city management

Zone \& land use

Environmental protection

Open space
To follow:

- City development policy

- Act 172

- RFN

Housing for poor people

Land use classification

Crematorium

Unnecessary high population target areas

Contradiction between plan statements on environmentally sensitive areas and detailed proposal

Contradiction between open space and green space development 


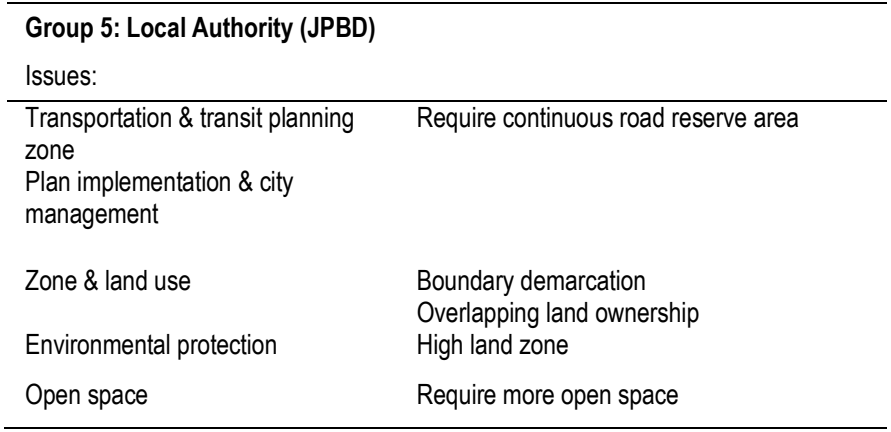

Significantly, 60,503 (97.2\%) opinions/ objections were found to be related to the local plans while only 2.8 percent were found to be not related. Those that were related were later categorized into accepted, rejected or noted categories based on the merit and suitability of the opinions. Significantly, 66.4 percent of all opinions were considered relevant and should be considered by the City Hall in the review of the Draft Plan later. These statistics showed that representations were knowledgeable about planning issues and able to articulate their view and objections effectively. They seem to understand their rights as landowners and citizens of Kuala Lumpur and how the plan can affect their lives.

During the public hearing process, the enthusiasms of the representatives were very evident. For certain controversial cases such as redevelopment of villages and relocating of squatters, the numbers of supporters were rather significant and they came by the busload. They were also vocal in their representations and argued actively before the panel. It should be noted that since most of the parliamentary seats in Kuala Lumpur were the opposition political parties, these parties representatives played a very active role in representing their constituencies. This is perhaps due to their perceptions that the Kuala Lumpur City Hall is a pro-establishment local government.

In terms of ethnicity, all three major ethnic groups of Kuala Lumpur, namely Malay, Chinese and Indians were represented in the public hearing process.

\subsection{Conclusion}

The outcome is expected to shed more insights into the process of public participation in planning in Malaysia and the levels of awareness and activisms of residents concerning the urban development of the Malaysian capital. It would show that in Kuala Lumpur at least, the public participation has entered a new height compared to just a decade earlier. 


\section{Acknowledgement}

The authors would like to extend the utmost appreciation to all participated agencies especially Kuala Lumpur City Council; public participated groups, Universiti Teknologi MARA and Kementerian Pendidikan Malaysia for their help and financial supports. The authors also acknowledge the constructive comments for reviewing the manuscript.

\section{References}

Abdul Karim, H. \& Abdul Rashid, S. M. (2010). Community participation: Towards a safer housing environment. Asian Journal of Environment-Behaviour Studies, 1(2), 19-32.

Cai, M. \& Wang, Y. M. (2012) Low-carbon tourism: A new mode of tourism development. Economy and Management, 01.

National Physical Plan (2005). Department of Town and Country Planning, Malaysia.

Peerapun, W. (2011). Participatory Planning approach to urban conservation and regeneration in Amphawa community, Thailand. Asian Journal of Environment-Behaviour Studies, 3(7), 35-44.

Wanarat, K. \& Nuanwan, T. (2013). Using 3D visualisation to improve public participation in sustainable planning process: Experiences through the creation of Koh Mudsum Plan, Thailand. Procedia - Social and Behavioral Sciences, 91(0), 679-690. doi:http://dx.doi.org/10.1016/j.sbspro.2013.08.469 